\title{
UJI DAYA HAMBAT EKSTRAK BATANG KAYU SECANG (Caesalpinia Sappan L.) TERHADAP BAKTERI Escherichia Coli
}

\author{
Ni Made Dwi Dharmayanti*, I Putu Dedy Arjita** \\ Fakultas Kedokteran Universitas Islam Al-Azhar \\ J1. Unizar No.20 Turida Mataram
}

\begin{abstract}
ABSTRAK
Escherichia coli merupakan bakteri gram negatif berbentuk batang dalam sel tunggal atau berpasangan. Escherichia coli termasuk anggota flora normal dalam usus dan dapat menjadi patogen bila mencapai jaringan di luar jaringan intestinal. Mengingat obat-obatan kimiawi banyak yang menyebabkan resistensi dan efek samping, para ahli farmakologi mulai mengembangkan pengobatan dengan bahan-bahan yang tradisional seperti tanaman secang (Caesalpinia sappan L.) yang bermanfaat sebagai antibakteri (Katno, 2008).

Tujuan penelitian ini adalah untuk mengetahui daya hambat ekstrak batang kayu secang (Caesalpinia sappan L.) terhadap bakteri Escherichia coli. Penelitian ini merupakan jenis penelitian True Experiment dengan rancangan Posttest dengan Kelompok Kontrol (Posttest Only Control Group Design), menggunakan Rancangan Acak Lengkap (RAL) dengan 24 unit percobaan dan 4 kali ulangan. Sampel penelitian adalah ekstrak batang kayu secang (Caesalpinia sappan L) dengan konsentrasi 10\%, 20\%, 30\% dan 40\%, 2 kelompok kontrol terdiri dari kontrol positif ciprofloxacin dan kontrol negatif aquades. Daya hambat diperoleh berdasarkan pengukuran zona hambat dan data yang diperoleh dianalisis menggunakan uji One Way Anova.

Hasil penelitian zona hambatan untuk Escherichia coli pada konsentrasi 10\% (0 mm); 20\% (0 mm); 30\% (0 mm) dan 40\% (0 mm). Hasil uji Kruskal Wallis diperoleh nilai signifikan yakni 1,000 lebih besar dari $p$ value: 0,05 sehingga dapat dinyatakan bahwa ekstrak batang kayu secang (Caesalpinia sappan L.) tidak memiliki daya hambat terhadap pertumbuhan bakteri Escherichia coli
\end{abstract}

Kata Kunci: Escherichia Coli, batang kayu secang (Caesalpinia sappan L.), zona hambat

\section{LATAR BELAKANG}

Penyakit infeksi merupakan penyebab utama morbiditas dan mortalitas di dunia. Menurut WHO (World Health Organization) pada tahun 2011, sebanyak 25 juta kematian di seluruh dunia, sepertiganya disebabkan oleh penyakit infeksi. Penyakit infeksi menjadi masalah kesehatan di dunia terutama di negara berkembang karena tingkat pengetahuan dan kesadaran akan pentingnya kesehatan penduduknya masih rendah. Sebagian besar penyakit infeksi tersebut disebabkan oleh bakteri (Radji, 2011).
Bakteri merupakan kelompok mahluk hidup bersel tunggal, masuk dalam golongan jasad renik atau mikroba karena tubuhnya sangat kecil sehingga tidak bisa dilihat dengan mata telanjang (Tjitrosoepono, 2005). Salah satu jenis bakteri yang sering menyebabkan infeksi adalah Escherichia coli, merupakan bakteri gram negatif berbentuk batang dalam sel tunggal atau berpasangan. Escherichia coli termasuk dalam anggota family Enterobacteriacea dan flora normal intestinal. Escherichia coli akan menjadi patogen bila mencapai jaringan di luar jaringan intestinal (Brooks GF, 2001). 
Sebagai upaya untuk pengobatan infeksi yang disebabkan oleh bakteri, saat ini para ahli farmakologi mulai mengembangkan pengobatan dengan bahan-bahan yang tradisional, mengingat obat-obat kimiawi banyak yang menyebabkan resistensi dan efek samping bagi penderita. Tanaman herbal yang biasa digunakan dikalangan masyarakat dan sampai saat ini masih dipercaya dapat menyembuhkan suatu penyakit seperti tanaman secang (Caesalpinia sappan L.) (Katno, 2008).

Secang merupakan tanaman famili Caesalpiniaceae yang banyak ditemui di Indonesia, secara empiris diketahui memiliki banyak khasiat penyembuhan dan sering dikonsumsi oleh masyarakat sebagai minuman kesehatan. Secang adalah tanaman berkayu yang biasa dimanfaatkan bagian batangnya (Praja, 2015). Batang kayu secang berbentuk bulat, berwarna hijau kecokelatan memberikan warna merah bila serutan kayunya direbus (Padmaningrum dkk, 2012). Kayu secang memiliki kandungan senyawa berupa brazilin $\left(\mathrm{C}_{16} \mathrm{H}_{14} \mathrm{O}_{5}\right)$, sappanin $\left(\mathrm{C}_{12} \mathrm{H}_{12} \mathrm{O}_{4}\right)$, brazilein, dan minyak atsiri seperti $\mathrm{D}$ - $\alpha$-felandrena, asam galat, oscimene, dan damar (Hally dkk, 2015).

Berdasarkan penelitian Wardani pada tahun 2012 yang berjudul "Aktivitas Antibakteri Ekstrak Etanol Kayu Secang
(Caesalpinia sappan L.) terhadap Staphylococcus aureus ATCC 25923, Shigella sonnei ATCC 9290, dan Escherichia coli ATCC 25922" dengan konsentrasi yang digunakan terhadap Staphylococcus aureus ATCC 25923 yaitu $0,05 \mathrm{mg}$; $0,1 \mathrm{mg}$; $0,2 \mathrm{mg}$; dan 0,4 $\mathrm{mg} /$ disc. Konsentrasi yang digunakan terhadap Shigella sonnei ATCC 9290 yaitu $0,025 \mathrm{mg}$; 0,05 mg; 0,1 mg; 0,2 mg; $0,3 \mathrm{mg}$; dan $0,4 \mathrm{mg} / \mathrm{disc}$ dan konsentrasi untuk Escherichia coli ATCC 25922 yaitu 0,5 mg; $1 \mathrm{mg}$; $2 \mathrm{mg}$; $3 \mathrm{mg}$; dan 4 mg/disc. Didapatkan hasil bahwa ekstrak etanol kayu secang lebih poten membunuh bakteri Staphylococcus aureus ATCC 25923 (0,4 mg/disc dengan zona hambat radikal $11,83 \mathrm{~mm}$ ) dibandingkan bakteri Shigella sonnei ATCC $9290(0,4 \mathrm{mg} / \mathrm{disc}$ dengan zona hambat radikal $11 \mathrm{~mm})$. Potensi antibakteri ekstrak etanol kayu secang terhadap bakteri Escherichia coli ATCC 25922 lebih kecil karena untuk menghambat maupun membunuh bakteri Escherichia coli ATCC 25922 dibutuhkan konsentrasi yang lebih besar $(0,5 \mathrm{mg} /$ disc dengan zona hambat radikal $6 \mathrm{~mm}$ ). Selain itu, berdasarkan penelitian Kumala dkk (2009) tentang pengaruh pemberian rebusan kayu secang (Caesalpinia sappan L.) terhadap mencit yang diinfeksi bakteri Escherichia coli menunjukan bahwa rebusan kayu secang dengan konsentrasi 
$10 \%, 20 \%$ dan $50 \%$ dapat menghambat pertumbuhan bakteri Escherichia coli.

Berdasarkan uraian diatas, peneliti ingin melakukan penelitian tentang uji daya hambat ekstrak batang kayu secang Caesalpinia sappan L.) terhadap bakteri Escherichia coli.

\section{METODE}

Penelitian dilaksanakan menggunakan eksperimen murni (True Experiment) dengan rancangan Posttest dengan Kelompok Kontrol (Posttest Only Control Group Design) (Notoatmodjo, 2012). Rancanangan yang dilakukan dalam penelitian ini adalah Rancangan Acak Lengkap (RAL) dengan 4 kelompok perlakuan yang terdiri atas ekstrak batang kayu secang (Caesalpinia sappan L.) dengan konsentrasi 10\%, 20\%, 30\%, 40\% dan 2 kelompok kontrol terdiri dari kontrol positif dengan menggunakan ciprofloxacin dan kontrol negatif menggunakan aquades steril.

Untuk membagi ruang lingkup variabel-variabel yang diteliti, maka variabel tersebut diberi batasan atau definisi operasional. Definisi operasional ini juga bermanfaat untuk mengarahkan kepada pengukuran atau pengamatan terhadap variabel-variabel / pengembangan instrument (Notoatmodjo, 2012) diantaranya adalah ekstrak batang kayu secang (Caesalpinia sappan L.) yaitu produk yang didapat dari hasil penyaringan simplisia dengan metode penyaringan tertentu (Dewi, 2010); diameter zona hambat Escherichia coli yaitu Zona bening yang muncul pada media MHA (Dewi, 2010).

\section{Pembuatan Ekstrak Air batang Kayu Secang (Caesalpinia sappan L.)}

Batang kayu secang didapat dalam bentuk serbuk. Pertama serbuk ditimbang 10 gram, dimasukan ke dalam panci ekstrak dan ditambah aquades steril 100 ml. Panci ekstrak kemudian dipanaskan selama 15 menit, terhitung mulai suhu 900 C, sambil sesekali diaduk. Kemudian disaring selagi panas dengan kain flannel dan ditambahkan air panas secukupnya melalui ampas hingga diperoleh $100 \mathrm{ml}$ (Depkes RI, 2014).

\section{Pembuatan Suspensi Escherichia coli}

Ambil satu ujung ose koloni dari Escherichia coli biakan murni, dimasukan ke dalam $3 \mathrm{ml} \mathrm{NaCl}$ 0,85\%. Selanjutnya bandingkan kekeruhan dengan standar 0,5 unit Mc Farland. Jika kekeruhannya >0,5 Mc Farland lakukan pengeceran sampai kekeruhan sama dengan 0,5 Mc Farland dengan menambahkan $\mathrm{NaCl}$ 0,85\%. Jika kekeruhannya kurang dari standar, tambahkan koloni bakteri.

\section{Uji Difusi Media Sumur}


Disiapkan suspense murni Diamati pada sumuran yang dimasukan Escherichia coli dengan kekeruhan 0,5 bahan ekstrak batang kayu secang Mc Farland. Disiapkan media MHA. Dioleskan suspense bakteri dengan swab kapas steril sehingga merata pada permukaan media, inkubasi kurang lebih selama 5-15 menit. Dibuat sumuran dengan menggunakan pentive steril yang ditekan pada permukaan media. (Caesalpinia sappan L.) dan kontrol, apabila hasilnya bening menandakan bahwa terjadi penghambatan pertumbuhan bakteri. Mengukur zona bening dengan menggunakan penggaris. Kemudian mencatat hasil yang didapat (Ramadanti, 2008).

Dimasukan ekstrak batang kayu secang (Caesalpinia sappan L.) pada masing-

\section{Analisis Data}

Semua data yang diperoleh 20\%, 30\%, 40\%, kontrol (-), dan kontrol (+) dengan volume masing-masing 1 tetes $( \pm 25 \mu)$ dan jumlah pengulangan (replikasi) 4 kali. Diinkubasi pada suasana aerob suhu $370 \mathrm{C}$ selama 24 jam. dilakukan uji statistik dengan One Way Anova yang memiliki tingkat kepercayaan 95\% $(p$ value $=0,05)$ dan dengan bantuan SPSS dilanjutkan dengan uji tukey HSD untuk mengetahui konsentrasi mana saja yang signifikan.

\section{HASIL DAN PEMBAHASAN}

\section{Hasil}

Tabel 4.1 Hasil uji ekstrak batang kayu secang (Caesalpinia sappan L.) terhadap bakteri Escherichia coli.

\begin{tabular}{|c|c|c|c|c|c|c|c|}
\hline \multirow{3}{*}{$\begin{array}{l}\text { Konsentrasi } \\
\text { Ekstrak Batang } \\
\text { Kayu Secang } \\
\text { (Caesalpinia } \\
\text { sappan L.) }\end{array}$} & \multicolumn{4}{|c|}{$\begin{array}{c}\text { Luas Zona Hambatan }(\mathrm{mm}) \\
\text { pertumbuhan bakteri }\end{array}$} & \multirow{3}{*}{$\begin{array}{l}\text { Jumlah } \\
\text { diameter }\end{array}$} & \multirow{3}{*}{ Rata-rata } & \multirow[b]{2}{*}{ Makna } \\
\hline & \multicolumn{4}{|c|}{ Replikasi } & & & \\
\hline & 1 & 2 & 3 & 4 & & & \\
\hline (t1) $10 \%$ & 0 & 0 & 0 & 0 & 0 & 0 & $\mathrm{R}$ \\
\hline (t2) $20 \%$ & 0 & 0 & 0 & 0 & 0 & 0 & $\mathrm{R}$ \\
\hline (t3) $30 \%$ & 0 & 0 & 0 & 0 & 0 & 0 & $\mathrm{R}$ \\
\hline (t4) $40 \%$ & 0 & 0 & 0 & 0 & 0 & 0 & $\mathrm{R}$ \\
\hline Kontrol (+) & 30 & 31 & 32 & 31 & 124 & 31 & $\mathrm{~S}$ \\
\hline Kontrol (-) & 0 & 0 & 0 & 0 & 0 & 0 & $\mathrm{R}$ \\
\hline
\end{tabular}


Sumber: Data hasil penelitian (2018)

Tabel 4.2 Hasil Uji Normalitas Data Menggunakan Saphiro Wilk

\begin{tabular}{|l|c|c|}
\hline \multicolumn{1}{|c|}{ Kelompok } & $\mathrm{N}$ & Diameter zona hambatan \\
\hline & & $\mathrm{P}$ \\
\hline Kontrol (+) & 4 & 0,272 \\
\hline
\end{tabular}

Tabel 4.3 Hasil Uji Homogenitas Data Menggunakan Levene

\begin{tabular}{|l|l|l|}
\hline & Levene's & $\mathrm{P}$ \\
\hline Diameter & 13,500 & 0,000 \\
\hline
\end{tabular}

Berdasarkan hasil uji statistik Bakteri yang digunakan dalam

dengan menggunakan Levene diperoleh penelitian ini berasal dari Laboratorium hasil $\mathrm{p}(1,000)>0,05$ maka dapat Mikrobiologi, Rumah Sakit Umum Pusat disimpulkan bahwa ekstrak batang kayu Sanglah Denpasar, Bali. Ekstrak batang secang (Caesalpinia sappan L.) tidak kayu secang (Caesalpinia sappan L.) memiliki daya hambat terhadap yang digunakan dalam penelitian ini pertumbuhan bakteri Escherichia coli (Ho adalah ekstrak yang dibuat di diterima).

\section{PEMBAHASAN}

Pada penelitian ini dilakukan uji daya hambat ekstrak batang kayu secang (Caesalpinia sappan L.) terhadap bakteri Escherichia coli dengan menggunakan metode sumur difusi. Kemampuan ekstrak batang kayu secang (Caesalpinia sappan L.) dalam menghambat bakteri Escherichia coli ditandai dengan munculnya zona bening disekitar sumuran. Luas zona hambat tersebut selanjutnya diukur pada tiap-tiap konsentrasi.
Laboratorium Terpadu I, Fakultas Kedokteran Universitas Islam Al-Azhar. Penelitian dilakukan di Laboratorium Terpadu I, Fakultas Kedokteran Universitas Islam Al-Azhar pada tanggal 3-4 Oktober dengan membagi ekstrak batang kayu secang (Caesalpinia sappan L.) menjadi empat konsentrasi yaitu $10 \%$, $20 \%, 30 \%$, dan $40 \%$ kemudian dibandingkan dengan kontrol positif (Ciprofloxacin) dan kontrol negatif (aquades). Pemilihan Ciprofloxacin karena telah terbukti memiliki efek antibakteri sedangkan pemilihan aquades digunakan sebagai pelarut yang tidak 
memiliki efek antibakteri sehingga tidak mempengaruhi hasil uji antibakteri.

Berdasarkan hasil penelitian diperoleh rerata zona hambat Ekstrak batang kayu secang (Caesalpinia sappan L.) terhadap bakteri Escherichia coli dengan konsentrasi 10\%, 20\%, 30\%, 40\% adalah $0 \mathrm{~mm}$. Ciprofloxacin selaku kontrol positif memiliki rata-rata diameter zona hambat terbesar $(32 \mathrm{~mm})$ dan aquades selaku kontrol negatif tidak menghasilkan diameter zona hambat $(0$ $\mathrm{mm})$, masing-masing perlakuan pada tiaptiap pengulangan disajikan dalam tabel 4.1.

Dalam buku medical laboratory technology, Mukherejje meyebutkan bahwa besar diameter zona hambat yang dibentuk oleh obat-obatan tradisional dikatakan sensitif bila diameter zona hambatan > $12 \mathrm{~mm}$, intermediet bila diameter zona hambatan 4-12 $\mathrm{mm}$ dan resistent bila diameter zona hambatan $<4$ mm (Buana, 2011). Berdasarkan pernyataan tersebut, maka dapat dikatakan bahwa ekstrak batang kayu secang (Caesalpinia sappan L.) tidak mampu menghambat bakteri Escherichia coli, dibuktikan dengan tidak terbentuknya zona hambatan pada media MHA (Muller Hinton Agar). Hal ini diduga karena kecilnya kelimpahan senyawa antibakteri dalam ekstrak batang kayu secang (Caesalpinia sappan L.) sehingga tidak cukup menembus dinding sel bakteri Escherichia coli untuk menimbulkan kerusakan. Dimana, struktur membran luarnya yang komplek terdiri atas lipoprotein, fosfolipida dan lipopolisakarida yang membatasi akses senyawa aktif ke dalam membran sel yang dapat dipenetrasi oleh senyawa antibakteri (Ariyanti dkk, 2012). Tidak adanya diameter zona hambat yang terbentuk oleh konsentrasi dari ekstrak batang kayu secang (Caesalpinia sappan L.) juga dapat dipengaruhi oleh berbagai faktor, seperti penggunaan aquades sebagai pelarut saat ekstraksi tidak sesuai, yang mengakibatkan zat antibakteri dalam kayu secang tidak mampu melepas senyawa aktif dari sel tanaman tersebut, sehingga tidak cukup menghambat pertumbuhan bakteri Escherichia coli (Fardhyanti, 2015).

Pelarut air memiliki tingkat kelarutan yang rendah dibandingkan dengan pelarut metanol dan etanol, dimana tingkat kelarutan air adalah $29,775 \%$, metanol 39,858\%, dan etanol $42,375 \%$. Rendahnya tingkat kelarutan tersebut menyebabkan kemampuan air dalam menyari senyawa metabolit menjadi kurang baik (Septiana, 2012). Selain faktor virulensi bakteri uji dan pemilihan pelarut dalam membuat ekstraksi, faktor lain diduga dapat mempengaruhi hasil uji aktivitas 
antibakteri yaitu faktor teknis. Faktor teknis yang mempengaruhi aktivitas antibakteri secara in vitro adalah lama inkubasi, suhu, dan jumlah inokulum (Brooks GF, 2001). Faktor-faktor tersebut dapat dikendalikan oleh peneliti selama melakukan penelitian. Lamanya inkubasi selama 24 jam, dan proses inkubasi juga telah diatur dalam keadaan yang optimal dengan suhu $37^{\circ} \mathrm{C}$. Jumlah inokulum telah disesuaikan dengan standar 0,5 Mc Farland, jumlah tersebut telah diukur menggunakan densi check.

Hasil penelitian ini bertolak belakang dengan hasil penelitian yang dilakukan oleh Kumala dkk (2009) tentang pengaruh pemberian rebusan kayu secang (Caesalpinia sappan L.) terhadap mencit yang diinfeksi bakteri Escherichia coli menunjukan bahwa, rebusan kayu secang dengan konsentrasi $10 \%$, 20\% dan 50\% dapat menghambat pertumbuhan bakteri Escherichia coli. Perbedaan hasil tersebut kemungkinan diakibatkan oleh konsentrasi bakteri yang ada pada mencit lebih rendah dibandingkan dengan konsentrasi bakteri pada perlakuan uji secara invitro, yang pertumbuhan bakterinya lebih murni dan subur (Mahon, 2015).

Untuk mendapatkan hasil yang lebih maksimal perlu dilakukan penelitian dengan metode ekstraksi yang berbeda, pelarut yang sama ataupun jenis-jenis yang lebih modern untuk menghasilkan larutan dengan kadar antibakteri yang lebih tinggi, sehingga dapat menghasilkan zona hambat. Selain itu dapat digunakan sebagai acuan untuk membuat ekstraksi yang menghasilkan larutan batang kayu secang (Caesalpinia sappan L.) dengan antibakteri yang bisa digunakan sebagai obat alternatif yang lebih alami oleh kalangan masyarakat.

\section{PENUTUP}

\section{Simpulan}

Berdasarkan hasil penelitian dan pembahasan maka dapat disimpulkan sebagai sebagai berikut:

Ekstrak batang kayu secang (Caesalpinia sappan L.) dengan konsentrasi 10\%, 20\%, $30 \%$, 40\%, tidak dapat menghambat pertumbuhan bakteri Escherichia coli.

\section{Saran}

1. Perlu dilakukan penelitian lebih lanjut membandingakan metode cakram disk (Kirby bauer) dengan metode sumuran.

2. Perlu adanya penelitian lebih lanjut mengenai daya hambat Ekstrak Batang Kayu Secang (Caesalpinia sappan L.) terhadap jenis bakteri lain sehingga dapat mengembangkan ilmu pengetahuan sebagai alternatif untuk menghambat bakteri. 
3. Bagi peneliti selanjutnya dapat dilakukan penelitian lanjutan mengenai Ekstrak Batang Kayu Secang (Caesalpinia sappan L.)

\section{DAFTAR PUSTAKA}

Ariyanti, N., Darmayasa, I., Sudirga, S. 2012. Daya Hambat Ekstrak Kulit Daun Lidah Buaya (Aloe barbadensis miller) Terhadap Pertumbuhan Bakteri Staphylococcus aureus ATCC 25923 dan Escherichia coli ATCC 25922. Jurnal Biologi XVI(1): 1- 4.

Brooks GF, Butel SJ, Morse AS. 2001. Medical Microbiology, International Edition. 22nd ed. New York: McGraw-Hill Co.

Buana, S. 2011. Pengaruh Perasan Daun Beluntas (Pluchea indica L.) Terhadap Pertumbuhan Bakteri Staphlococus aureus. Skripsi. Fakultas Kedokteran Universitas Islam Al-Azhar: Mataram.

Depkes RI. 2014. Farmakope Indonesia Edisi V. Jakarta.

Dewi, F.K., 2010, Aktivitas Antibakteri Ekstrak Etanol Buah Mengkudu (Morinda citrifolia L.) terhadap Bakteri Pembususk Daging Segar [Skripsi S-1], Jurusan Biologi FMIPA, Universitas Sebelas Maret, Surakarta.

Fardhyanti, Dewi Selvia dan Ria Dwita Riski. 2015. "Pemungutan Brazilin dari Kayu secang (Caesalpinia Sappan L.) dengan Metode Maserasi dan Aplikasinya untuk Pewarnaan Kain”. Jurnal Bahan Alam Terbarukan Semarang State University. Vol. 4. No. 1. ISSN 2303-0623. menggunakan pelarut yang berbeda, maupun menggunakan variasi konsentrasi yang berbeda.

Hally, Farhana. Indra TM, Reza AK. 2015. "Perbandingan Pengaruh Suhu dan Waktu Perebusan terhadap Kandungan Brazilin pada Kayu Secang (Caesalpinia Sappan Linn)". Prosiding Penelitian SPeSIA Unisba. ISSN: 2460-6472.

Katno, Pramono S. 2008. Tingkat Manfaat dan Keamanan Tanaman Obat dan Obat Tradisional. Balai Penelitian Obat Tawangmangu, Fakultas Farmasi Universitas Gajah Mada. Yogyakarta: Fakultas Farmasi UGM.

Kumala S. dan Tulus D. 2013. Aktivitas Antibakteri Rebusan Secang (Caesalpinia sappan L.) Terhadap Salmonella thypii secara In Vivo Antibacterial Activity of Boiled Secang Extract (Caesalpinia Sappan L.) Againts Salmonella typhii in Vivo.

Mahon, Connie R, Donald C. Lehman, dan George Manuselis. 2015. Textbook Of Diagnostic Microbiology Fifth Edition. Cina: Library of Congress Cataloging in Publication Data.

Notoatmodjo. 2012. Metodologi Penelitian Kesehatan. Jakarta : PT. Rineka Cipta.

Padmaningrum, R. T., Siti, M., dan Antuni, W. 2012. Karakter ekstrak zat warna kayu secang (Caesalpinia sappan L.) sebagai indikator titrasi asam basa. Prosiding Seminar Nasional Penelitian, Pendidikan dan Penerapan MIPA, Fakultas MIPA, Universitas Negeri Yogyakarta. 
Praja, D. I. 2015. Zat Aditif Makanan Manfaat Dan Bahayanya. Yogyakarta: Garudhawaca.

Radji, M. 2011. Buku Ajar Mikrobiologi Panduan Mahasiswa Farmasi dan Kedokteran. Jakarta: EGC.

Ramadanti I. 2008. "Uji aktivitas antibakteri ekstrak bawang putih (Allium sativum Linn) terhadap bakteri Escherichia coli in vitro".

Artikel Karya Tulis Ilmiah. Universitas Diponegoro.

Septiana AT dan Asnani A. 2012, Kajian Sifat Fisikokimia Ekstrak Rumput
Laut Coklat Sargassum duplicatum Menggunakan Berbagai Pelarut dan Metode Ekstraksi, Jurnal Agrointek; Volume 6, No. 1.

Tjitrosoepono, G. 2005. Taksonomi Tumbuhan. Yogyakarta: Gadjah Mada University Press.

Wardani, Yunita Dinar. 2012. "Aktivitas Antibakteri Ekstrak Etanol Kayu Secang (Caesalpinia sappan L.) Terhadap Staphylococcus aureus ATCC 25923, Shigella sonnei ATCC 9290, dan Escherichia coli ATCC 25922". Skripsi. Universitas Muhammadiyah Surakarta. 